\title{
Pedotransfer Functions for Estimating ESP \& SAR for Arid Soils in the Eastern Region of Libya
}

\author{
Ahmed Y. Habel ${ }^{1}$
}

\begin{abstract}
Most of the applied methods to determine the Exchangeable Sodium Percentage (ESP) and Sodium Adsorption Ratio (SAR) are time consuming and sometimes expensive, especially in calcareous soils, due to the dissolving of $\mathrm{CaCO}_{3}$ and $\mathrm{Mg} \mathrm{CO}_{3}$ during the chemical analysis and then erroneously driving to an increase of Cation Exchange Capacity (CEC) value. To work around these problems, many researchers have developed Pedotransfer Functions $\left(\mathrm{PTF}_{\mathrm{S}}\right)$ as an attempt to estimate these parameters from easy-to-obtain some soil characteristics such as Electrical Conductivity (EC). In this work, linear regression models using the $\mathrm{EC}$ as a predictor for estimating the ESP and SAR were developed with high recommended determination coefficients. In order to validate these models, they were applied to estimate ESP and SAR from EC for 26 soil samples collected from AlJabal Al-Akhdar in the eastern region of libya. The paired samples t-test analysis of these compared samples showed no significant difference between the laboratory measurements and those estimated by the regression models.
\end{abstract}

Key words: Exchangeable Sodium Percentage, Sodium Adsorption Ratio, Electrical Conductivity, PTF $_{S}$, Libya

\section{INTRODUCTION}

Libya can be said to be an arid country, because the average annuall rainfall is less than $100 \mathrm{~mm}$, covering about $93 \%$ of the country (Ismail, 2007). Generally under these conditions, evaporation and evapotranspiration are not compensated by the precipitation and the irrigation water, so the chance to flush out the accumulated salts from the root zone is little (Bresler $e t$. al., 1982). As a result, the saline soils are developed throughout the country. In addition, the application of irrigation water with poor quality may result in an increase of soil salinity hazards (Szabolcs, 1998).

The excessive accumulation of salts in the root zone have some negative effects on plant growth; such as reduction of water availability through the action of osmotic pressure, hinder the growth by toxic effects, and it may also result in unbalanced nutrients uptake by plants (Donahue et al., 1990; Brady and Weil, 2002). On the other hand, the adsorbed sodium under alkaline conditions often affects the plant growth by the specific toxicity and nutrient deficiencies. Also, it usually manifests its destructive effect on soil structure, producing poor physical conditions such as: increased surface crusting and then a low infiltration rate leading to excessive surface runoff and erosion (Gopalibardhan et. al., 2007).

In general, the recognized criterion to identify salt affected soils is based on the measurement of salts content by the Electrical Conductivity (EC), of the saturated soil extract with border $>4\left(\mathrm{dS} . \mathrm{m}^{-1}\right)(\mathrm{SSSA}$ 1997). The sodium hazard of soil is usually expressed as Sodium Adsorption Ratio (SAR) with reported threshold of $13\left(\mathrm{Cmol}^{+1} \cdot \mathrm{Kg}^{-1}\right)$, and the Exchangeable Sodium Percentage (ESP) with reported threshold of $15 \%$ (Richards, 1954) .These are defined in the following equations (1) and (2):

$$
\mathrm{SAR}=\mathrm{Na}^{+} /\left[\left(\mathrm{Ca}^{2+}+\mathrm{Mg}^{2+)} / 2\right]^{0.5}\right.
$$

Where:

$\mathrm{Na}^{+}, \mathrm{Ca}^{2+}$ and $\mathrm{Mg}^{2+}$ : measured soluble sodium, calcium and magnesium, respectively $\left(\mathrm{mmol} \cdot \mathrm{L}^{-1}\right)$.

$E S P=\left(\mathrm{Na}^{+} / \mathrm{CEC}\right) * 100$

Where:

$\mathrm{Na}^{+}$: measured exchangeable sodium $\left(\mathrm{Cmol}^{+1} \cdot \mathrm{Kg}^{-1}\right)$; CEC: cation exchange capacity $\left(\mathrm{Cmol}^{+1} \cdot \mathrm{Kg}^{-1}\right)$.

As shown in equations (1) and (2), for determining the soil SAR and ESP, it is necessary to determine the exchangeable cations such as $\mathrm{Na}^{+}, \mathrm{Ca}^{2+}, \mathrm{Mg}^{2+}$ and $\mathrm{K}^{+}$. This therefore leads to a lot of time, coupled with the chance of mistakes during the laboratory work. The other problem is that, extraction of exchangeable $\mathrm{Ca}^{2+}$ and $\mathrm{Mg}^{2+}$ during chemical analysis might dissolve some of $\mathrm{CaCO}_{3}$ and $\mathrm{MgCO}_{3}$, existing in soil and erroneously driving to an increase of CEC values, especially in Calcareous Soils (Oustan et al., 2007).

Based on the above facts, it will be more convenient and economical to develop such a method which determines soil SAR and ESP, using Pedotransfer Functions $\left(\mathrm{PTF}_{\mathrm{s}}\right)$ from more readily measured property, such as soil salinity index (EC).

"The Pedotransfer Function (PTF) is used as translating data we have into what we need" (Bouma 1989). Recently, many successful attempts have been done to estimate the difficulty in determining soil property utilizing easy or available measured soil properties by empirical models (Drake and Motto, 1982;

\footnotetext{
${ }^{1}$ Soil \& Water Department, Faculty of Agriculture -

Omar Al Mukhtar University, El- Bieda - Libya

Received January 23, 2013, Accepted March28, 2013
} 
Bell and Keulen, 1995). All these models were developed to predict soil cation exchange capacity (CEC), based on the organic carbon, clay fraction and soil $\mathrm{pH}$. Other researchers stated a relationship between the soil Sodium Adsorption Ratio (SAR) and the soil Electrical Conductivity (EC) (Richards 1954; Levy and Hillel, 1968; Emerson and Bakker, 1973; Al-Busaidi and Cookson, 2003).

Most of the above predictive models are specific to a certain region, and may substantially vary from clay minerals types present in the soil and ionic strength ( Evangelou and Marsi, 2003). Relatively, there have been considerable amount of work done by many researchers to show the relationships between the soil chemical properties.

The main goal of this research was to determine the optimum soil models for the sake of predicting the ESP and SAR, based on the EC for some Libyan soils.

\section{MATERIALS AND METHODS}

Twenty six soil samples were taken randomly from different profiles at Al- Jabal Al-Akhdar region in the eastern part of Libya (Al Izziyat) area, situated at latitude of $32^{\circ}-07^{\prime} \mathrm{N}$ and longitude of $22^{\circ}-40^{\circ} \mathrm{E}$ (Map 1).
The monthly temperatures mean vary between $11^{\circ} \mathrm{C}$ in January and $28^{\circ} \mathrm{C}$ in July, with mean annual temperatures of $20^{\circ} \mathrm{C}$. While the mean monthly rainfall is very low during the year, and is practically absent during summer season (June-August), with annual rainfall mean about $55 \mathrm{~mm}$.

The land is entirely located on alluvial sediments made up mostly of silt-loamy soils or finer materials, especially in the subsoil and subordinately of sand loam soils. The substratum is generally made of small and coarse pebbly alluvial, resting on bedrock which being made up of limestone. From a strictly geomorphologic point of view, the study area belongs to a single landscape characterized by an ample depression, closed laterally by limestone hills, which are cut by small wadis that debouch at the borders of the flat surface, contributing to the slow accumulation of the sediments. The absence of natural outlet of the precipitation and surface running waters create, although temporarily and in the more depressed central part, the stagnation of these waters, and consequently enriching the soil in salt both on and below the surface (Ismail, 2007).
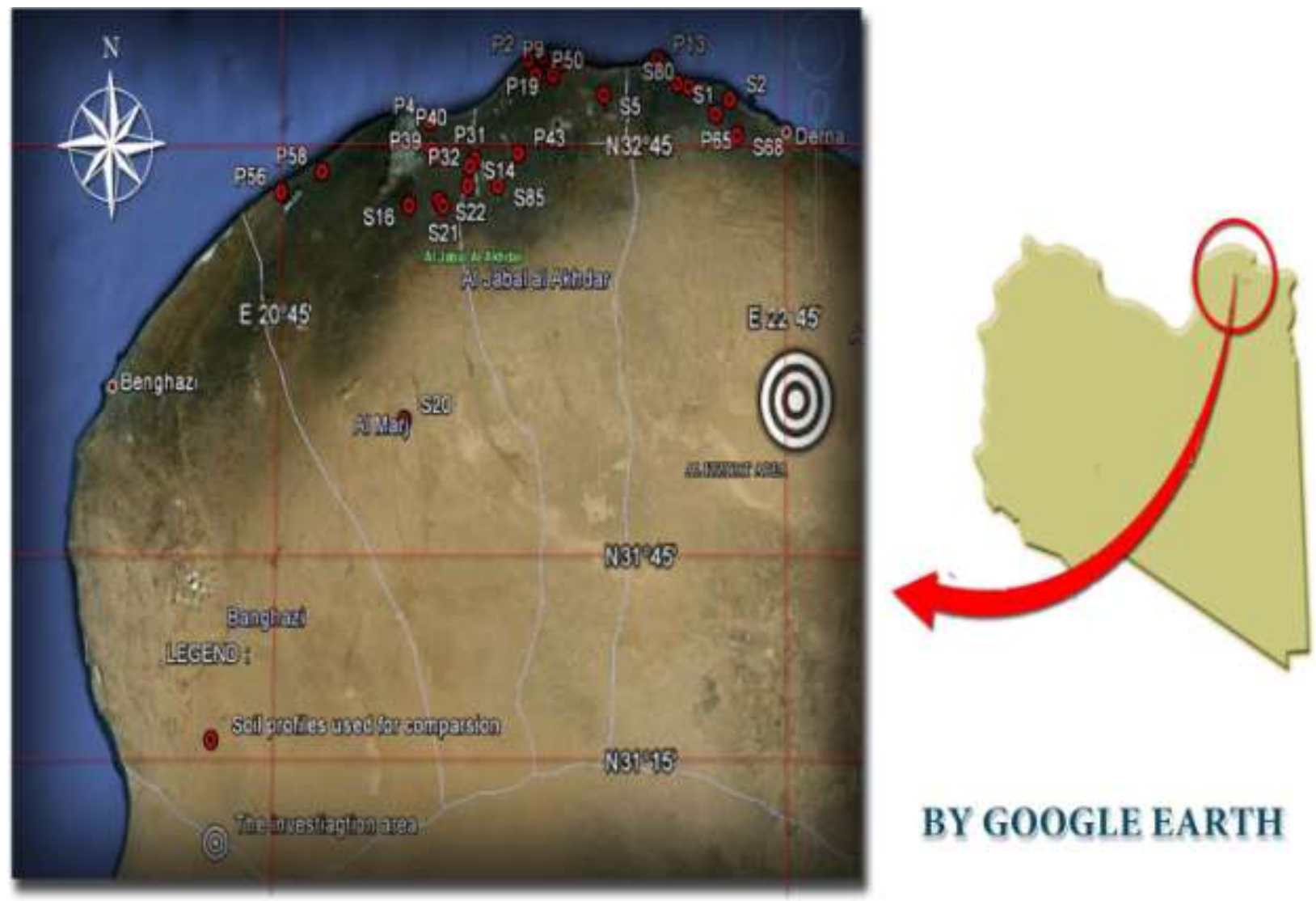

BY GOOGLE EARTH

Figure 1. location of the studied soil profiles 


\section{RESULTS AND DISCUSSIONS}

Statistical analysis of physical and chemical properties of 26 soil samples used to determine ESP and SAR Pedotransfer Functions are presented in Tables (1) and (2).

These results indicate that the prevalence of soil samples having basic soil reaction, oscillates between 8.0 to 9.4 with mean about 8.65 , as well as high content of calcium carbonate with mean $42.71 \%$, so they may be subtend as silty loam textured-calcareous soils.

A significant depression in the organic matter content is well observed, as it ranges between 0.40 and $2.02 \%$ with mean of $0.90 \%$. This may be directly related to the dry and arid climatic conditions, which prevail in this region (low annual precipitation associated with high temperature). According to the mean value of EC, ESP and SAR of soil samples, these soils may be classified as saline-sodic soils. The coefficient of variation (CV) of the EC, ESP, SAR and $\mathrm{Na}$ showed more variability than those of other soil properties. This high variation of these properties imparts generality to the findings and allows them to be applied with greater reliability to other soils.

The correlation coefficients between all measured soil variables are given in Table (2). The reverse correlation between calcium carbonate content with silt and clay contents and CEC, is noticeable, while it was significantly proportional with sand content. This indicates that calcium carbonate content in these soils has a coarse texture as a result of the slow weathering processes.
The correlation coefficient between $\mathrm{pH}$ and $\mathrm{EC}$ of investigated soil samples was obviously negative (0.649). This could be interpreted by the increase degree of dissociation of surface functional groups, replacement of adsorbed $\mathrm{H}$-ions by cations of the saline soil solution (Oustan et al., 2007).

As it was expected, there is a significant negative correlation between the CEC and sand content (-0.817), whereas, it shows positive correlations $(0.761,0.583)$ for silt and clay contents respectively. This positive correlation may be contributed to the large surface area of these components. (Manrique et al., 1991; Bell and keulen, 1995)

The results indicated that ESP and SAR values increased with increasing of soil salinity, supported with high levels of correlations coefficients of 0.877 and 0.93, respectively. The measured ESP and SAR were plotted against EC, as shown in Figures (2) \& (3). This will facilitate the accuracy of height to develop models for prediction ESP and SAR from EC measurements.

The coefficients of determination $\left(\mathrm{R}^{2}\right)$ of these regression equations are judged acceptable, so they may suggest models of greater predictive ability to estimate the Exchangeable Sodium Percent (ESP), and Sodium Adsorption Ratio (SAR) from the Soil Salinity (EC), as in Equations 4 and 5.

$\mathrm{ESP}=3.358+0.3909 \mathrm{EC} \quad$ Equation 4. $\mathrm{SAR}=2.303+0.4023 \mathrm{EC} \quad$ Equation 5 .

To verify the usability of these regression equations, they were applied to predict the ESP and SAR for twenty six soil samples, selected with paid attention to the similarity of the environmental conditions to the

Table 1. Descriptive statistics of some soil properties

\begin{tabular}{lccccc}
\hline \multicolumn{1}{c}{ Variable } & Minimum & Maximum & Mean & SD & CV \% \\
\hline Sand \% & 2.00 & 85.00 & 27.77 & 19.28 & 69.43 \\
\hline Silt \% & 12.90 & 77.10 & 55.89 & 15.26 & 27.30 \\
\hline Clay \% & 2.10 & 39.90 & 16.04 & 47.40 & 47.40 \\
\hline $\mathrm{pH}$ & 8.00 & 9.40 & 8.65 & 0.30 & 3.46 \\
\hline $\mathrm{CaCO} \%$ & 23.80 & 69.80 & 42.71 & 11.75 & 27.51 \\
\hline $\mathrm{OM} \%$ & 0.40 & 2.02 & 0.90 & 0.37 & 42.01 \\
\hline $\mathrm{EC}\left(\mathrm{dS} \cdot \mathrm{m}^{-1}\right)$ & 0.37 & 54.88 & 6.26 & 11.92 & 190.30 \\
\hline $\mathrm{CEC}\left(\mathrm{Cmol}^{+} . \mathrm{kg}^{-1}\right)$ & 6.34 & 20.16 & 13.50 & 3.15 & 23.31 \\
\hline $\mathrm{ESP} \%$ & 1.00 & 24.00 & 5.81 & 5.31 & 91.50 \\
\hline $\mathrm{SAR}$ & 1.00 & 26.00 & 4.82 & 5.16 & 106.89 \\
\hline $\mathrm{Na}^{+}\left(\mathrm{Cmol}^{+} . \mathrm{kg}^{-1}\right)$ & 0.11 & 3.56 & 0.75 & 1.05 & 110.94 \\
\hline $\mathrm{K}^{+}\left(\mathrm{Cmol}^{+} . \mathrm{kg}^{-1}\right)$ & 0.37 & 4.74 & 2.28 & 1.07 & 47.05 \\
\hline$\left[\mathrm{Ca}^{+2}+\mathrm{Mg}^{+2}\right]\left(\mathrm{Cmol}^{+} . \mathrm{kg}^{-1}\right)$ & 4.94 & 15.06 & 10.30 & 2.55 & 24.82 \\
\hline
\end{tabular}


Table 2. Correlation coefficients of the measured soil properties

\begin{tabular}{|c|c|c|c|c|c|c|c|c|c|}
\hline Property & Sand & Silt & Clay & pH & $\mathrm{CaCO}_{3}$ & $\mathbf{O M}$ & EC & CEC & ESP \\
\hline Silt $\%$ & $-0.924^{* *}$ & & & & & & & & \\
\hline Sig.(2-tailed) & .000 & & & & & & & & \\
\hline Clay $\%$ & $-0.672^{* *}$ & $0.367^{* *}$ & & & & & & & \\
\hline Sig.(2-tailed) & .000 & .003 & & & & & & & \\
\hline $\mathrm{pH}$ & 0.092 & -0.171 & 0.178 & & & & & & \\
\hline Sig.(2-tailed) & .475 & .183 & & & & & & & \\
\hline $\mathrm{CaCO}_{3} \%$ & $0.878^{* *}$ & $-0.777^{* *}$ & $-0.691^{* *}$ & 0.007 & & & & & \\
\hline Sig.(2-tailed) & .000 & .000 & .000 & .955 & & & & & \\
\hline OM \% & -0.189 & $0.323^{*}$ & -0.177 & $-0.365^{* *}$ & -0.217 & & & & \\
\hline Sig.(2-tailed) & 0142 & .011 & .169 & .004 & .089 & & & & \\
\hline $\mathrm{EC}\left(\mathrm{dS} . \mathrm{m}^{-1}\right)$ & -0.085 & 0.140 & -0.156 & $-0.649^{* *}$ & -0.081 & -0.081 & & & \\
\hline Sig.(2-tailed) & 0510 & 0279 & .227 & .000 & .530 & .534 & & & \\
\hline CEC & $-0.817^{* *}$ & $0.761^{* *}$ & $0.583^{* *}$ & 0.028 & $-0.760^{* *}$ & 0.149 & 0.145 & & \\
\hline Sig.(2-tailed) & .000 & .000 & .000 & .829 & .0000 & .249 & .261 & & \\
\hline ESP \% & -0.093 & 0.093 & -0.027 & $-0.577^{* *}$ & 0.051 & -0.145 & $0.877^{* *}$ & 0.116 & \\
\hline Sig.(2-tailed) & .473 & 0473 & .835 & .0000 & .695 & .261 & .000 & .369 & \\
\hline SAR & -0.090 & 0.129 & -0.091 & $-0.554^{* *}$ & 0.065 & -0.099 & $0.930^{* *}$ & 0.165 & $0.942^{* *}$ \\
\hline Sig.(2-tailed) & .486 & .319 & .484 & .0000 & .616 & .446 & .000 & .199 & .000 \\
\hline
\end{tabular}

** Correlation is significant at the 0.01 probability level $(\mathrm{N}=26)$.

*Correlation is significant at the 0.05 probability level $(\mathrm{N}=26)$.

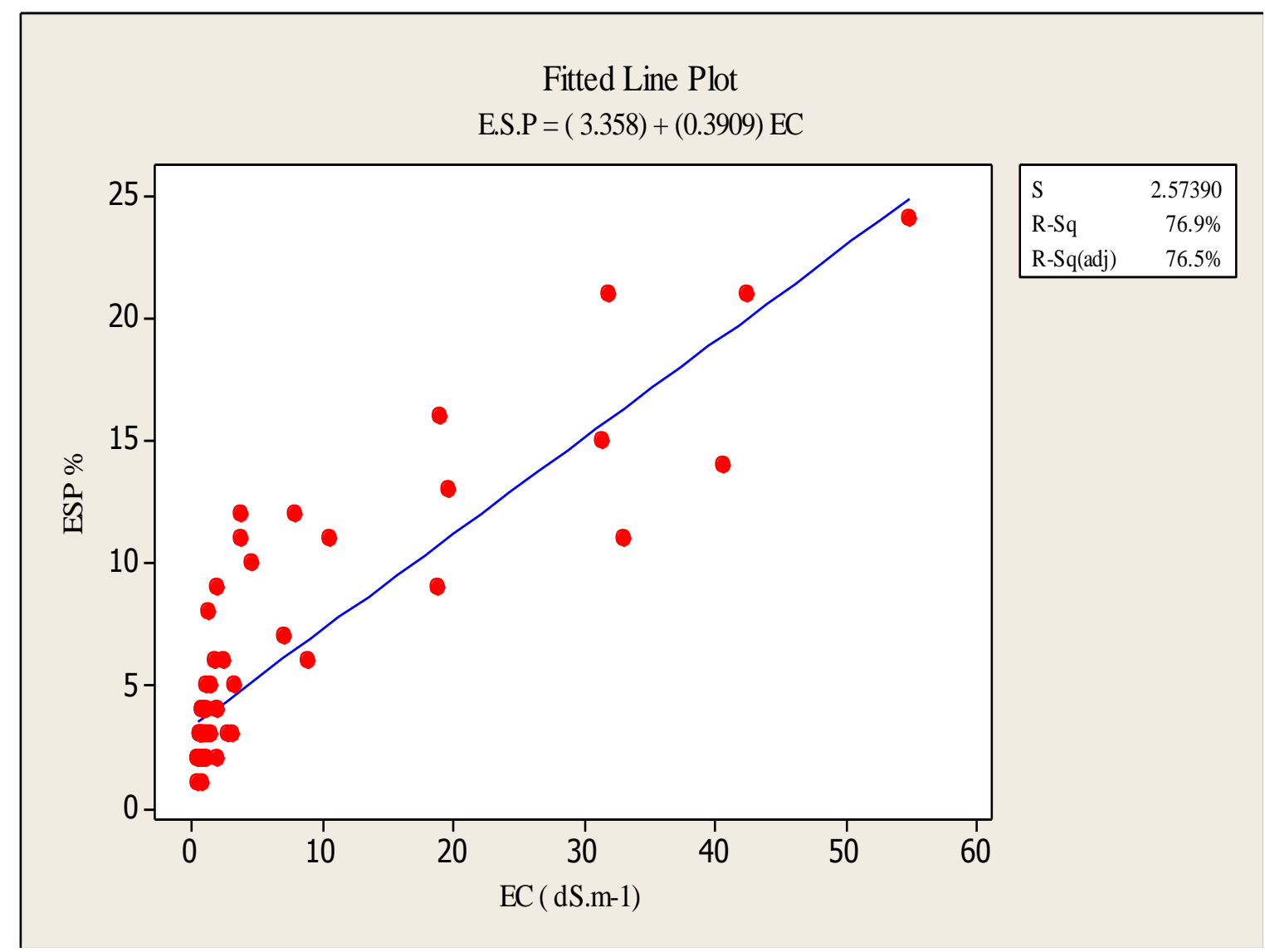

Figure 2.The regression equation of EC and ESP of tested soil samples 


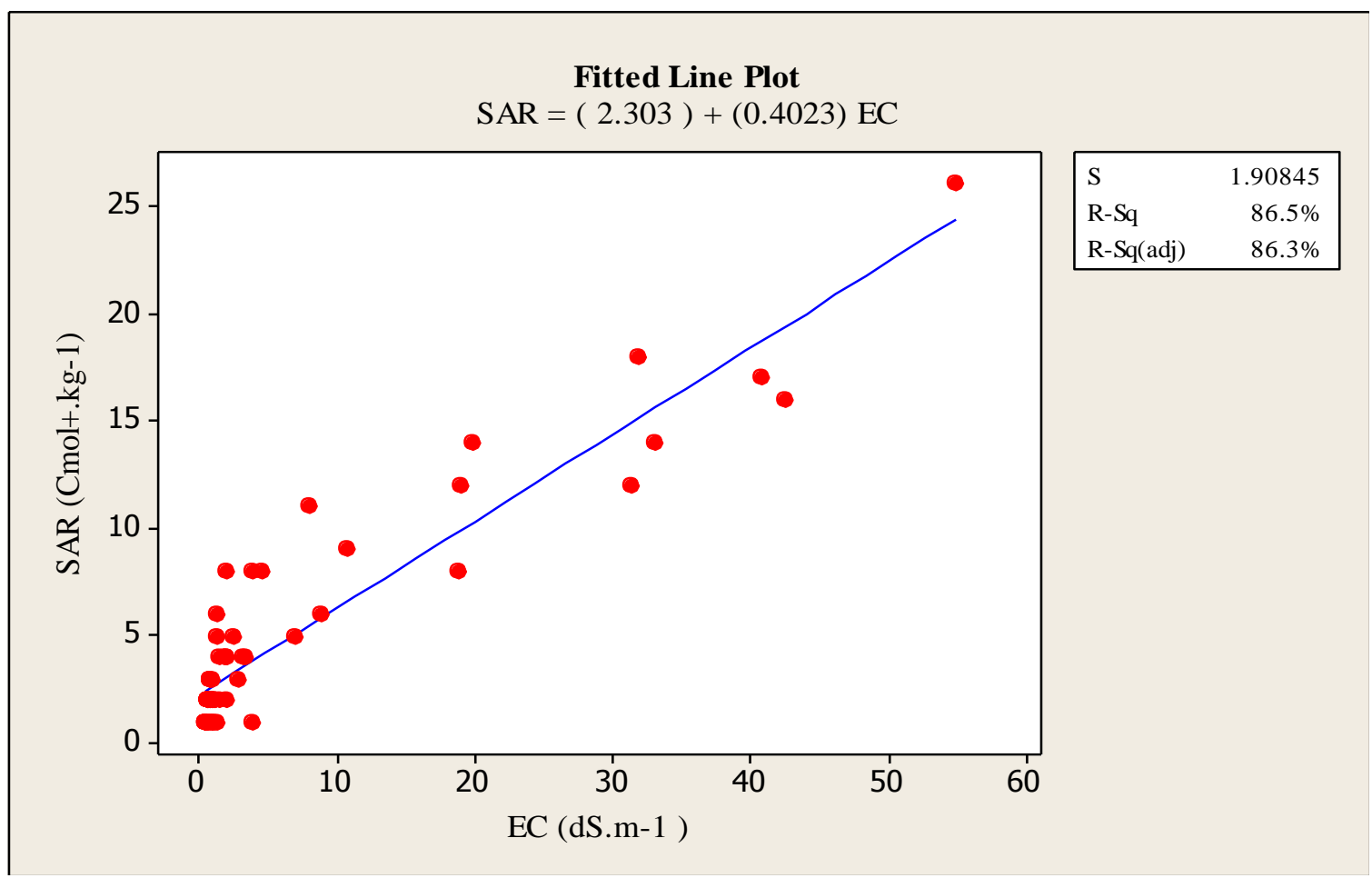

Figure 3. The regression equation of EC and SAR of tested soil samples

investigation area, from "The study and evaluation of the vegetation cover of Jabal Al Akhdar " (Omar AlMukhtar University, 2005). The statistical analyses of soil physical and chemical properties of these soil samples are presented in Table (3).

A paired samples t-test and mean difference confidence interval approach were used to compare between predicted and measured ESP and SAR values. The results of comparison analyses are presented in Table (4).

The outcomes of the paired samples t-test analyses indicated that there were no significant differences between predicted and measured ESP and SAR values (Rashidi and Seilsepour, 2008).
As, there were no significant differences between predicted and measured ESP and SAR values, thus, the predicted values were plotted against the measured EC. The, ESP and SAR are quitely proportional with the EC (Fig. 4).

\section{CONCLUSIONS}

Because of the opportunity of mistakes during the laboratory tests, time consuming and the costs of the investigations, it can be concluded that, regression equations showed a valuable and economical tool to predict the ESP and SAR values with high accuracy levels under the similar environmental conditions.

Table 3. Statistical analysis of the soil samples used for the verification

\begin{tabular}{lccccc}
\hline \multicolumn{1}{c}{ Parameter } & Minimum & Maximum & Mean & $\begin{array}{c}\text { Standard } \\
\text { Deviation }\end{array}$ & $\begin{array}{c}\text { Coefficient of } \\
\text { Variation }(\mathbf{C V} \text { \%) }\end{array}$ \\
\hline Sand (\%) & 13.37 & 60.75 & 25.33 & 10.2 & 40.28 \\
\hline Silt $(\%)$ & 26.92 & 48.04 & 37.75 & 6.02 & 15.94 \\
\hline Clay $(\%)$ & 9.35 & 53.92 & 36.92 & 10.83 & 29.36 \\
\hline $\mathrm{pH}$ & 7.26 & 8.59 & 7.84 & 0.32 & 4.06 \\
\hline EC $\left(\mathrm{dS} . \mathrm{m}^{-1}\right)$ & 1.40 & 9.30 & 2.83 & 1.65 & 58.51 \\
\hline $\mathrm{CEC}\left(\mathrm{C} \mathrm{mol}^{+} . \mathrm{Kg}^{-1}\right)$ & 10 & 28.83 & 18.98 & 5.91 & 31.3 \\
\hline ESP $(\%)$ & 1.51 & 7.13 & 3.78 & 1.6 & 42.3 \\
\hline SAR & 1.51 & 7.13 & 3.78 & 1.6 & 42.3 \\
\hline
\end{tabular}


Table 4. Paired samples t-test analyses on comparing soil ESP \& SAR determinations methods

\begin{tabular}{lcccccc}
\hline Property & Mean & St .Dev. & SE Mean & p-value & t-value & 95\% CI for the mean difference \\
\hline ESP $(\%)$ & 0.308 & 1.60 & 0.313 & 0.335 & 0.98 & $(-0.338,0.954)$ \\
\hline SAR & -0.125 & 0.852 & 0.167 & 0.463 & -0.75 & $(-0.469,0.219)$ \\
\hline
\end{tabular}
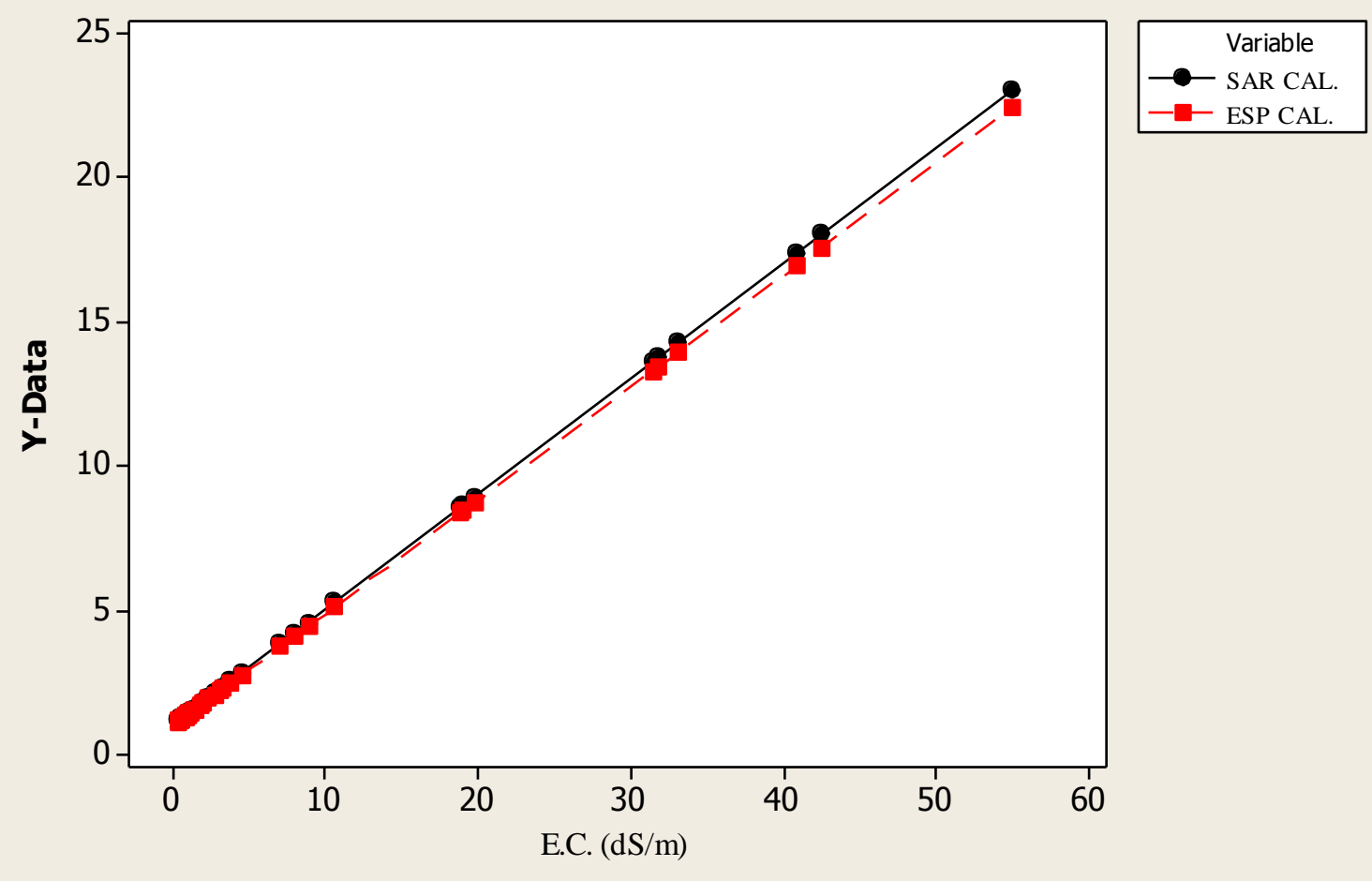

Figure 4: The relationship between EC, ESP and SAR

REFERENCES

Al-Busaidi A.S., and P. Cookson (2003). Salinity - pH relationships in calcareous soils. Agriculture and Marine Sciences. 8: 41-46.

Bell M.A. and J.V. Keulen (1995). Soil pedotransfer functions for four Mexican soils. Soil Sci. Soc. Am. J., 59:865-871.

Bouma J. (1989).Using soil survey data for quantitative land evaluation. Advances in soil science.9:177-213.

Brady, N. C., and R. R. Weil (2002). The Nature and Properties of Soils (13th Edition). Upper Saddle River, NJ: Prentice-Hall, Inc. pp: 415-431

Bresler E, Mcneal BI, and D.L. Carter (1982) 'Saline and sodic soils: principles, dynamics, modelling'. (SpringerVerlag: New York).

Donahue .R.I., M.W.Raymond and J.C. Chickluna (ed.), (1990). Soils : An introduction to soils and plant growth. Prentice Hall of India .pp :667.

Drake E.H. and H.L. Motto (1982). An analysis of the effect of clay and organic matter content on the cation exchange capacity of New Jersey soils. Soil Sci., 133: 281-288.
Emerson W.W. and A.C. Bakker (1973). The comparative effects of exchangeable calcium, magnesium and sodium on some physical properties of red-brown earth sub-soils. II. The spontaneous dispersion of aggregates in water. Australian Journal of Soil Research. 11 : 151-157.

Evangelou V.P. and M. Marsi (2003). Influence of ionic strength on sodium-calcium exchange of two temperate climate soils. Plant and Soil .250: 307-313.

Gopalibardhan , S.K. Chaudhari and P.K. Mohapatro (2007). Effect of irrigation water quality on saturated hydraulic conductivity of Typic Haplustert, Vertic Haplusterept, and Lithic Ustorthen soils. Jour.Agric. Physics,vol.7, pp.3846.

Ismail, A., (2007). The phenomena of drought in the Libyan region of Jabal Al Akhdar ( Climatic Study). Ph.D. Thesis. Faculty of Arts. Jordan University

Levy R. and D.Hillel (1968). Thermodynamics equilibrium, constants of sodium-calcium exchange in some Israel soils. Soil Science. 106:393-398.

Manrique L.A., C.A.Jones and P.T.Dyke (1991). Predicting cation-exchange capacity from soil physical and chemical properties. Soil Sci. Soc.Am., 55: 787-794. 
Omar Al-Mukhator University (2005). The study and evaluation of the vegetation cover of Jabal Al Akhdar . Final Report.

Oustan S., A.Jafarzadeh and N.Aliasgharzad (2007). Electrical conductivity as a salient factor in saline-sodic soils of Tabriz plain. Bioclimatology and Naatural Hazards .International Scientific Conference, Polana nad Detvos,Slovakia, September 17-20 .

Rashidi M. and M.Seilsepour 2008). Sodium adsorption ratio pedotransfer function for calcareous soils of varamin region. Int. J. Agri. Biol. 10: 715-8.
Richards L.A.(1954) .Diagnosis and improvement of saline and alkali soils. USDA Washington DC.

SSSA (1997). Glossary of Soil Science Terms; Soil Science Society of America: Madison, WI ; 134 pp.

Szabolcs, I. (1998). Salt buildup as a factor of soil degradation. In Methods for Assessment of Soil Degradation; Lal, R., Blum, W.H., Valentine, C., Stewart, B.A., Eds.; CRC Press: Boca Raton, FL, 253-264.

U.S.D.A. (2011). Soil Survey Laboratory Information Manual. Rep.45, Version 2.0.

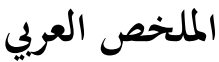

استخدام وظائف نقل البيانات الارضية للتنبؤ بكل من النسبة المئوية للصوديوم المتبادل ونسبة الصوديوم المدمص في بعض الأراضي الجافة في شرق ليبيا

$$
\text { أحمد يوسف هبيل }
$$

المعلومات من بعض خصائص التربة سهلة التقدير مثل التوصيل

معظم الأساليب المتبعة لتحديد النسبة المئوية للصوديوم المتبادل

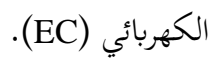

(ESP)

Eي هذا البحث، وضعت نماذج الانحدار الخطي باستخدام

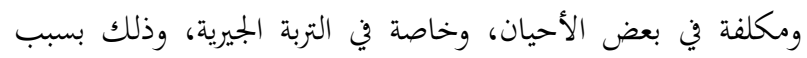
باعتباره مؤشرا لتقدير SARP و SAR. و من أجل التحقق من صحة ذوبان بعض كربونات الكالسيوم والمغنيسيوم خلال التحليل الكيميائي هذه النماذج، تم تطبيقها على التنبؤ بـ ESP و SAR من EC لعينات والذي قد يؤدي إلى زيادة قيمة الكاتيونات المتبادلة. في محاولة للتغلب التربة التي تم جمعها من منطقة العزيات بالجبل الأخضر - شرق ليبيا. على هذه المشاكل، استخدم العديد من الباحثين وظائف نقل

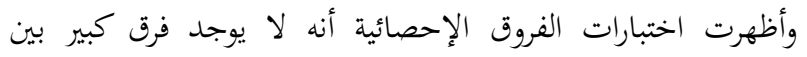

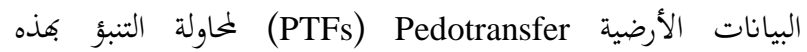
القياسات المختبرية وتلك المقدرة من قبل نماذج الانحدار. 